\title{
Water Footprint (ISO 14046) in Latin America, State of the Art and Recommendations for Assessment and Communication
}

\author{
Andrés Martínez-Arce ${ }^{1}$, Juan Pablo Chargoy ${ }^{1}$, Maly Puerto ${ }^{2}$, Diana Rojas ${ }^{2}$ and \\ Nydia Suppen ${ }^{1, *}$ \\ 1 Center for Life Cycle Assessment and Sustainable Design, State of Mexico 54766, Mexico; \\ amartinez@centroacv.mx (A.M.-A.); jpchargoy@centroacv.mx (J.P.C.) \\ 2 Embassy of Switzerland in Colombia-Swiss Agency for Development and Cooperation (SDC), \\ Bogotá 110221, Colombia; maly.puerto@eda.admin.ch (M.P.); diana.rojas@eda.admin.ch (D.R.) \\ * Correspondence: nsuppen@centroacv.mx; Tel.: +52-55-2602-9694
}

Received: 15 September 2018; Accepted: 21 October 2018; Published: 26 October 2018

\begin{abstract}
Due to the importance of water management, and good governance for humanity's wellbeing and future, the 2030 Sustainable Development Agenda has established the global Water Goal (SDG 6). Mobilization of the different sectors is required. The private sector has an important role, and it is increasingly aware of the substantial water risks for business. Thus, it is timely to quantify and monitor potential environmental impacts with an international standard (ISO 14046:2014), in order to prioritize investments to reduce the direct and indirect impacts from water uses within the production of goods and services. The objectives of this project were: (1) To scale knowledge, networking and generate leadership through exchanges among 43 professionals from 14 Latin American countries; (2) to develop recommendations to improve coherence in the quantification, verification and communication of the water footprint in the region; and (3) to structure and publish the recommendations, available tools/methods and key challenges in open access guidelines. This effort resulted in an active and continuous-growth community for water footprint practice in Latin America. This article describes the process to achieve the Regional Guidelines and other results.
\end{abstract}

Keywords: water footprint; Latin America; ISO 14046; impacts; water uses; guidelines recommendations

\section{Introduction}

The 11th Global Risk Report, developed through the consensus of almost 750 experts and published by the World Economic Forum indicates that, globally, the water crisis is perceived as one of the ten most relevant risks for humanity [1].

In particular, the Latin American and Caribbean region concentrates almost a third of the world's water resources; however, the resource is distributed unevenly throughout the territory [2]. In addition, there are problems associated with water management and governance, such as high levels of losses by leakages, due to the poor conditions of infrastructure, or the increasing deterioration of water quality, due to pollution [2]. Therefore, initiatives to promote sustainable water use are appropriate and necessary. There are two main approaches for water footprint assessment widespread: The first one developed by Hoekstra et al. [3], promoted by the Water Footprint Network (WFN), which maps three water footprints: Blue (consumptive use of surface or groundwater), green (rain water stored in the soil and absorbed by the plants) and grey water (freshwater required for assimilating the load of the main pollutant) and assesses the sustainability, efficiency and equitability of water use. The second framework, from the International Organization for Standardization (ISO) standard ISO 14046:2014 [4], is used to determine the potential environmental impacts related to water use along the life cycle 
of a product, process or organization. The water footprint can be represented by one single impact category (identified with a qualifier e.g., water scarcity footprint) or a profile, preferably addressing both water degradation and availability. The ISO 14046 framework is based on a life cycle assessment and the modeling of environmental mechanisms (systems of biological, physical or chemical processes), which allows the quantification of impacts and/or damages.

The Swiss Government through SDC's Global Water Program, established the "El Agua Nos Une-SuizAgua" initiative in 2009 in Colombia [5], as a public-private partnership with large companies with three purposes: (1) assessment and reduction of the water footprint (applying the ISO 14046 standard); (2) implementation of collective action in the territory for water risk management; (3) capacity development and knowledge sharing for scaling up. As of 2012, this initiative was scaled to Peru and Chile, and from 2018 to Ciudad de México and Sao Paulo, Brazil.

Through the experience gained with "El Agua Nos Une-SuizAgua" initiative, a growing demand from the business sector was identified and some challenges were faced in the assessment of the water footprint [6]. Despite the existence of documents that provide recommendations for conducting water footprint studies in accordance with ISO 14046:2014 [7-9], there was a lack of documented experience in Latin America. Previous studies have shown that the scientific consensus during the development of impact assessment methods has led to an increase in the certainty of the results of Life Cycle Assessment (LCA) studies [10], and it has been argued that without a scientific consensus, LCA could be used for green washing, decreasing the credibility of the studies [11]. In this context, for example, the European Commission led an effort involving representatives of 27 Member States and Advisory Groups from business associations, database and software developers, as well as impact assessment method developers, for the recommendation of impact assessment methods for LCA studies [12]. Studies analyzing the evolution of the conceptual framework of the water footprint, as well as the limitations of the methodologies, have mostly been created with a global scope and do not consider the particular limitations for studies conducted in the Latin American region [13,14]. Additionally, these studies did not consider the aspect of communication of the results. Thus, the objective of the present study was to generate knowledge regarding water footprinting practice in Latin America and to create a community of practice in the region to provide leadership in the application of the ISO 14046:2014. The aim of this effort was to generate recommendations to achieve consistency in the quantification, verification and communication of the water footprint in Latin America. These recommendations were documented in the Regional Guidelines, entitled: "Water footprint (ISO 14046) in Latin America, analysis and recommendations towards regional coherence", that are available in the supplementary materials.

\section{Materials and Methods}

The study methods could be best described by a mixed method with emphasis on qualitative methods or QUAL [15], as described in Table 1. Each activity is presented in the following sections.

Table 1. Research methodology.

\begin{tabular}{cc}
\hline Activity & Data Collection Types \\
\hline Contact with stakeholders & $\begin{array}{c}\text { E-mail contact and exchange } \\
\text { Telephone/web-based interviews }\end{array}$ \\
\hline $\begin{array}{c}\text { Desk based research of water } \\
\text { footprint studies in Latin America }\end{array}$ & $\begin{array}{c}\text { Public and private document analysis } \\
\text { Remote work sessions }\end{array}$ \\
$\begin{array}{c}\text { Online Focus group interviews } \\
\text { Interviews and e-mail surveys (open and closed } \\
\text { questions) }\end{array}$ \\
\hline Face-to-face work sessions & $\begin{array}{c}\text { Focus Group Interview } \\
\text { Closed survey with statistical validation }\end{array}$ \\
\hline Drafting the document & (analytical hierarchical method (AHP) method, $n=26)$ \\
\hline
\end{tabular}




\subsection{Contact with Stakeholders}

Since this initiative is focused on the practical assessment of the water footprint, stakeholders from different sectors were included: Companies, government institutions, academy and scientific institutions, consultancy, accreditation and verification bodies. Research for stakeholders with experience in the subject, allowed them to identify and send personalized invitations to 59 professionals from 15 countries in the region. The professionals invited to participate in the project were selected from: Project partners in LCA, water footprint projects and contacts from corporate water management events across Latin America. They were selected and invited based on: Experience in LCA and/or water footprinting in the curriculum vitae, origin (to promote the participation of representatives from different Latin American countries), and gender equality. Participants from government, academy, accreditation and verification bodies were privileged over those from the consulting sector, but the most expertise came principally from the latter.

\subsection{Research of Water Footprint Studies in Latin America}

To understand the state of the art of water footprint quantification in Latin America, reports and articles in scientific journals, websites of universities, institutes, internal project reports, among other sources, were researched. The research was conducted mainly through web browser both in English and Spanish using the following key words: "Product water footprint", "water footprint assessment", "ISO 14046", "water consumption" in combination with terms such as "Latin America" or the name of several countries in the region. Initially, the research was designed to find studies assessing the water footprint of products manufactured in any Latin American country following ISO 14040/44/46; however, the search showed few results with these characteristics, since most studies in Latin America used the framework of the WFN, assessing not only products, but also geographical regions or entire economic sectors. Consequently, the focus of the search was broadened to include the maximum amount of studies to understand the state of the art in Latin America. Also, the stakeholders were requested to share references and reports of studies to include them in the analysis. No restrictions were applied regarding the date of publication of the studies.

\subsection{Remote Work Sessions}

Based on the analysis of the studies and the experience gained through El Agua Nos Une initiative, six remote sessions were designed and carried out through webinars over six months, to discuss the relevant issues identified to achieve the development of the Guidelines with the recommendations for the application and communication of ISO 14046:2014 studies in Latin America.

The topics discussed in the sessions were the following:

- Collection of data to prepare water footprint inventories

- Impact categories and impact assessment methods

- Good practices for the communication of water footprint studies

- Future of the water footprint assessment in Latin America

Prior to each work session, material was created for the consultation of the participants, including presentations with concepts and topics of relevance, as well as points for reflection to analyze during the sessions.

During the remote sessions, group engagement dynamics were carried out to promote stakeholder participation, such as direct participation for the presentation of success stories or through the application of online surveys to know the group's point of view on each topic. Group discussions were also held to propose solutions involving stakeholders. The use of surveys is a methodology that has been used successfully in other cases for scientific consensus during the development of impact assessment methods in LCA $[10,16]$. 


\subsection{Face-to-Face Work Session}

The face-to-face session was held on 27 October 2016 in the City of Bogotá, Colombia. This work session served to review the progress made during the remote sessions and to deepen each topic to reach conclusions. The work dynamics for each topic are described below:

For the topics of data collection and communication of the water footprint, work tables were set up to discuss possible solutions to the problem of the lack of access to information in the region, as well as to the most appropriate schemes to communicate the results of studies of water footprint in Latin America. Subsequently, the results obtained from the work tables were contrasted with each other to reach a consensus.

For the topic of recommendation of impact assessment methods for the region, the analytical hierarchical method (AHP) was used. The AHP is a multi-criteria process of peer evaluation for complex group decision making that allows to measure the uniformity of alternatives and the relative agreement between opinions and has been used for decision making in LCA studies [17]. To evaluate the impact assessment methods, a brainstorm was conducted to determine the most relevant characteristics when recommending the use of a method. Subsequently, impact assessment methods were evaluated, considering these characteristics for the following impact categories: Freshwater scarcity, freshwater availability, freshwater ecotoxicity and freshwater eutrophication. Additionally, work tables were implemented to discuss the possibilities of regionalization of impact assessment methods.

The future plans and activities of the community of practice were discussed in an open plenary with all the participants.

\subsection{Drafting the Document}

The conclusions of the working sessions were condensed into a document. The writing was done through an iterative process of review by the participants, which consisted of three review rounds. In each case, the most current version of the document was provided along with a format for the record of comments. Each round the comments made by the participants were analyzed and answered and the suggested modifications were applied in the document.

\section{Results}

\subsection{Stakeholders of Water Footprint in Latin America}

Forty-three professionals out of the 59 initially invited, responded and accepted to participate in the project, representing 14 of the 15 countries initially considered. The largest number of participants came from the consulting sector $(37 \%)$ and academia $(21 \%)$, a possible reason is that in these sectors is where the greatest disclosure of the methodology is found. On the other hand, there was a high participation of accreditation and verification bodies (19\%), due to their interest of developing an eco-labeling scheme for the region.

Participation in the development of recommendations for regional coherence by country and by sector is shown in Figure 1.

The stakeholder's active involvement allowed a continuous-growth community for water footprint practice to be established, further referred to as the community of practice. 


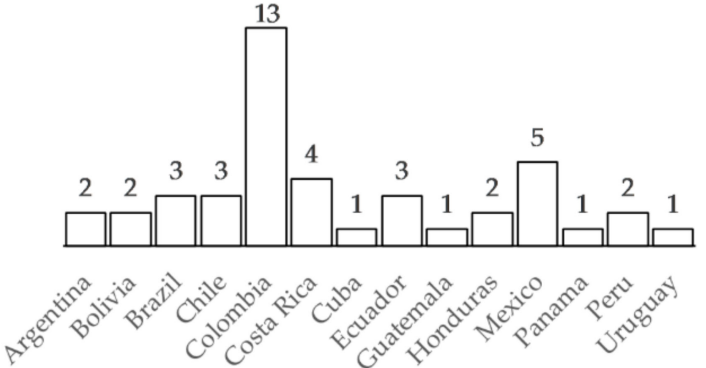

(a)

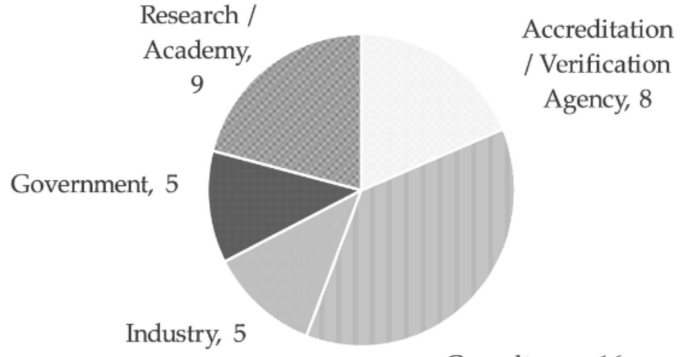

(b)

Figure 1. Analysis of the participants in the initiative to elaborate recommendations for the regional coherence of application of the water footprint ISO 14046:2014 (a) by country; (b) by type of institution. The numbers shown represent the number of people in each case.

\subsection{State of the Art of the Water Footprint in Latin America}

Table 2 shows the findings of the desk-based research of water footprint studies in Latin America. The table is arranged by country and presents the product or sector for which a water footprint assessment was carried out and the type of framework followed.

Table 2. State of the art in the quantification of the water footprint and the water footprint in Latin America. Modified from CADIS-COSUDE (2016) [18].

\begin{tabular}{|c|c|c|}
\hline \multirow{2}{*}{ Country } & \multicolumn{2}{|l|}{ Product, Service or Sector Under Analysis } \\
\hline & Water Footprint Network (WFN) & Life Cycle Assessment (LCA)/ISO 14046:2014 \\
\hline Argentina & $\begin{array}{l}\text { Product: Soybean [19], milk through various } \\
\text { production systems: Pastoral System (SP), Pastoral } \\
\text { Base System (SBP) and Intensive Pastoral Base } \\
\text { System (SBPI) [20], peanut [21], grape for wine [22]. } \\
\text { Sector: Agricultural and livestock of the province of } \\
\text { San Luis [23]. }\end{array}$ & Product: Milk [24], grape for wine [22]. \\
\hline Bolivia & $\begin{array}{l}\text { Production systems: Drinking water, soft drinks, } \\
\text { isotonic, energizers [25]. } \\
\text { Geographical: Cities of La Paz, Quito, Lima, Santa } \\
\text { Cruz de la Sierra, Guayaquil, Fortaleza, Loja, Santa } \\
\text { Cruz de Galápagos, Recife, Cali and Tarija.For the } \\
\text { evaluation, the residential, commercial, industrial, } \\
\text { public, municipal services and government activities } \\
\text { (administrative, service and operational) were } \\
\text { considered [25]. }\end{array}$ & \\
\hline Brazil & $\begin{array}{l}\text { Geographical: Seven river basins considering the } \\
\text { sectors: Livestock, agriculture, reforestation, supply } \\
\text { and sanitation [26]. } \\
\text { Product: Cosmetics including shampoo, soap and } \\
\text { moisturizers [27]. } \\
\text { Service: Hydroelectric power generation [28], food } \\
\text { consumption by one person [29]. }\end{array}$ & Product: Hydrated ethanol [30]. \\
\hline Chile & $\begin{array}{l}\text { Geographical: Rapel River basin considering the } \\
\text { sectors: Agricultural, mining, domestic and energy } \\
\text { [31]. } \\
\text { Product: Copper oxide mineral and copper sulfide } \\
\text { mineral [32]. }\end{array}$ & $\begin{array}{l}\text { Chemicals plant factory [33], mall operation, dry } \\
\text { milk production, PVC pipes factory, cement } \\
\text { production and hydroelectricity generation } \\
\text { (unpublished, presented at the Water Week Latin } \\
\text { America 2015 [34]). }\end{array}$ \\
\hline Colombia & $\begin{array}{l}\text { Country, by sector: Agricultural [35], domestic, } \\
\text { industrial, electrical and oil [36]. } \\
\text { Geographical: Porce River Basin considering the } \\
\text { sectors: Agricultural, industrial, domestic, } \\
\text { hydroelectric power generation and mining [37]. } \\
\text { Product: Japanese Lily [38], limestone [39], rice [40], } \\
\text { flowers [41], cocoa [42], corn [43], potato [44]. }\end{array}$ & $\begin{array}{l}\text { Product: Cement, concrete, tissue paper } \\
\text { (hygienic, napkins, kitchen towels, facial tissues } \\
\text { and moist products), feminine hygiene products, } \\
\text { food products, heating and cooling products, } \\
\text { precious metals (gold), cardboard boxes, banana } \\
\text { snacks [6]. } \\
\text { Production plants: Farms for the cultivation and } \\
\text { benefit of bananas, operation of a chemical } \\
\text { products plant, operation of a dairy products } \\
\text { factory, and operation of an agrochemical } \\
\text { production plant [6]. }\end{array}$ \\
\hline
\end{tabular}


Table 2. Cont.

\begin{tabular}{|c|c|c|}
\hline \multirow{2}{*}{ Country } & \multicolumn{2}{|l|}{ Product, Service or Sector Under Analysis } \\
\hline & Water Footprint Network (WFN) & Life Cycle Assessment (LCA)/ISO 14046:2014 \\
\hline Costa Rica & Product: Coffee, banana, rice [45]. & Production plant: Banana packing plant [46]. \\
\hline Ecuador & Products: Banana [47], roses [48]. & \\
\hline Mexico & Geographical: Country [49]. & $\begin{array}{l}\text { Products: Wheat, corn, water for urban public } \\
\text { use, advisory service for water treatment [50]. } \\
\text { Sector: Agricultural, brewer, cement [51]. } \\
\text { Geographical: Water scarcity factor in } 13 \\
\text { administrative hydrological regions [51]. }\end{array}$ \\
\hline Peru & Product: Banana [47]. & $\begin{array}{l}\text { Product: Polyvinyl chloride pie [52], asparagus } \\
\text { [53], ice cream [54], thermoelectric power [55]. }\end{array}$ \\
\hline $\begin{array}{l}\text { Regional (Latin } \\
\text { America) }\end{array}$ & $\begin{array}{l}\text { Geographical: Countries of Latin America } \\
\text { considering consumption in agricultural, livestock } \\
\text { and industrial sectors [56]. }\end{array}$ & \\
\hline Uruguay & $\begin{array}{l}\text { Production system: Intensive, extensive and mixed } \\
\text { cattle [57]. }\end{array}$ & \\
\hline
\end{tabular}

A total of 40 water footprint studies were identified for the Latin American context. Most of the studies (28 studies) developed in the region are based on the framework promoted by the Water Footprint Network (WFN) [3]. The first studies developed specifically for Latin America are from the year 2011 [19,35]. The concepts of the LCA began to be applied as of 2013 for the evaluation of the environmental impact related to water scarcity [50,51]. This indicates that the application of methodologies to assess the impacts associated with water use in Latin America, with a life cycle approach, is a relatively recent practice and there are interesting opportunities for developing studies in the region. These results are in accordance with the water footprint assessment practice in the world, as documented in Aivazidou et al. [14] critical literature synthesis. The authors found that most of the studies published until May 2016, followed the WFN framework. The authors also found an increase in publications in the last years, indicating the relevance of evaluating impacts related to water use; but a general lack of a holistic approach with a life cycle perspective in the water footprint studies analyzed [14].

Despite the inherent differences between the WFN and ISO 14046:2014 frameworks, the stakeholder group concluded that the two are complementary and useful, as it can be observed in Lovarelli et al. [58], who developed a Pollution Water Indicator (PWI) based on grey water indicator, calculated according to WFN, as well as on three environmental potential impact categories assessed with the LCA approach: Freshwater eutrophication, marine eutrophication and freshwater ecotoxicity. PWI complements grey water (focusing only on the main water pollutant) through including the effects of all substances emitted during agricultural practices. The stakeholder group agreed that both approaches are helpful when complex decision making, regarding the sustainability of water resources in the region, arises.

Additionally, it was identified that, regardless of the framework used, one of the main sectors quantifying the water footprint, was the agrifood sector ( $78 \%$ of the analyzed studies). This is relevant considering that approximately $70 \%$ of the water extracted in the world is for agricultural use [59], showing the awareness that exists regarding the importance of evaluating the impact associated with the use of water in the agricultural sector in Latin America. The importance of the agrifood sector has been previously noted. For example, Aviazidou et al. found, as a result of a critical literature synthesis with global scope, that most of the studies published in a peer-review journal were focused on water related impacts of the agrifood sector (61\%) [14]. Lovarelli et al. [13] conducted a review analysis of water footprint studies of agricultural products. The focus on agriculture was due to this sector being a major water consumer worldwide. The authors found that studies often quantify blue water without information about irrigation efficiency, which could imply an underestimation of the impact [13]. In this regard, Garcia-Morillo et al. proposed a methodology for linking blue water footprint assessment with irrigation indicators, considering the efficiency in water use regarding crop 
requirements, including agronomic practices such as soil preparation, plantation, salt removal from soil and reduction of frost effects [60]. These last two studies were done after carrying out the state of art research of the present study, but their conclusions are relevant to the recommendations from the stakeholder group to work towards strengthening the current work in the agricultural sector, through the development of coherent data and impact assessment methods.

\subsection{Data Collection Recommendations for Water Footprint Studies in Latin America}

The data collection experience of the different stakeholders was shared during the working sessions. Both data availability and quality were discussed and analyzed. Table 3 lists the main obstacles that were identified for the topic of obtaining data for water footprint studies in Latin America, as well as the recommended solution.

Table 3. Main obstacles to collect data for water footprint studies in Latin America and recommended solutions. Modified from CADIS-COSUDE (2016) [18].

\begin{tabular}{lll}
\hline Obstacle & Description & Recommended Solution \\
$\begin{array}{l}\text { The information available is not } \\
\text { geographically or statistically } \\
\text { representative }\end{array}$ & $\begin{array}{l}\text { Life cycle databases required for water footprint } \\
\text { studies are designed for other geographic } \\
\text { contexts, for example, Europe or the United } \\
\text { States. }\end{array}$ & $\begin{array}{l}\text { It is possible to obtain useful information } \\
\text { through government institutions on issues such } \\
\text { as water availability, volume of authorized } \\
\text { water for consumption, sanitation coverage, } \\
\text { among others. }\end{array}$ \\
\hline $\begin{array}{l}\text { The information that is required is } \\
\text { not known }\end{array}$ & $\begin{array}{l}\text { There are not enough water footprint studies in } \\
\text { Latin America to form a complete life cycle } \\
\text { database applicable to the region. }\end{array}$ & $\begin{array}{l}\text { It is recommended to make adaptations to the } \\
\text { databases and document these adaptations in a } \\
\text { transparent manner in the reports. }\end{array}$ \\
\hline $\begin{array}{l}\text { The measurement and monitoring } \\
\text { mechanisms are insufficient }\end{array}$ & $\begin{array}{l}\text { Frequently, there are no flow meters in the } \\
\text { companies and existing ones do not always have } \\
\text { a calibration certificate. }\end{array}$ & $\begin{array}{l}\text { Promote the installation of measuring } \\
\text { equipment and certify the correct calibration of } \\
\text { the equipment from authorized instances at the } \\
\text { national level in each country. }\end{array}$ \\
\hline Confidentiality of information & $\begin{array}{l}\text { Frequently, companies protect their information, } \\
\text { which hinders the disclosure of inventories. }\end{array}$ & $\begin{array}{l}\text { A possible solution is the signing of } \\
\text { confidentiality agreements at the beginning of } \\
\text { the studies, in order to allow the use of the } \\
\text { impact result per functional unit, to avoid } \\
\text { revealing data. }\end{array}$ \\
\hline
\end{tabular}

According to the group, these problems are related to a general lack of awareness in the region about the importance of water resources, so it is recommended to make an effort to disseminate the importance of corporate water management in Latin America [18].

\subsection{Impact Assessment-Recommendations for the Evaluation of the Water Footprint in Latin America}

\subsubsection{Considerations on the Selection of Impact Categories}

According to ISO 14046:2014, impact categories to be quantified in a water footprint should be chosen according to the goal and scope of the study. However, the stakeholder group concluded that there may be general recommendations by type of product. For example, in the case of a water footprint study of an agricultural product, it is recommended to include the impact category of eutrophication. In countries with an energy mix, including a high portion of hydroelectric power, it is important to analyze an indicator that determines the potential impacts linked to the construction of the infrastructure i.e., the dams. It is also recommended to review the existence of Product Category Rules (PCR) for Environmental Product Declarations (EPD), since these provide a reference with respect to the impact categories to be evaluated for each type of product [18].

Impacts related to water are associated with numerous environmental mechanisms and therefore numerous category indicators and water footprint impact assessment methods can be used. A category indicator is the quantifiable representation of an impact category. Regarding the category indicators, the stakeholder group concluded that the choice of these indicators, also depends on the intended audience, for example, if the study has a scientific nature, it is recommended to choose the category midpoints to conserve the objectivity and scientific robustness of the impact categories assessed. 
The use of category endpoints, is recommended for screening studies, to evaluate the categories that have greater relevance for each particular product [18]. Category midpoints are considered links in the cause-effect environmental mechanism of an impact category; common examples are climate change, eutrophication or ecotoxicity. Endpoint indicators (damages to ecosystem quality, human health and resources) reflect the relative importance of emissions or extractions at the end of the cause-effect chain, e.g., changes in biodiversity [61].

\subsubsection{Impact Assessment Methods for Water Footprint Studies in Latin America}

The stakeholder group responded to a survey that allowed the identification of the most used impact categories for the development of water footprint studies in Latin America- These impact categories are: Freshwater scarcity, freshwater ecotoxicity, freshwater availability and freshwater eutrophication (Figure 2).

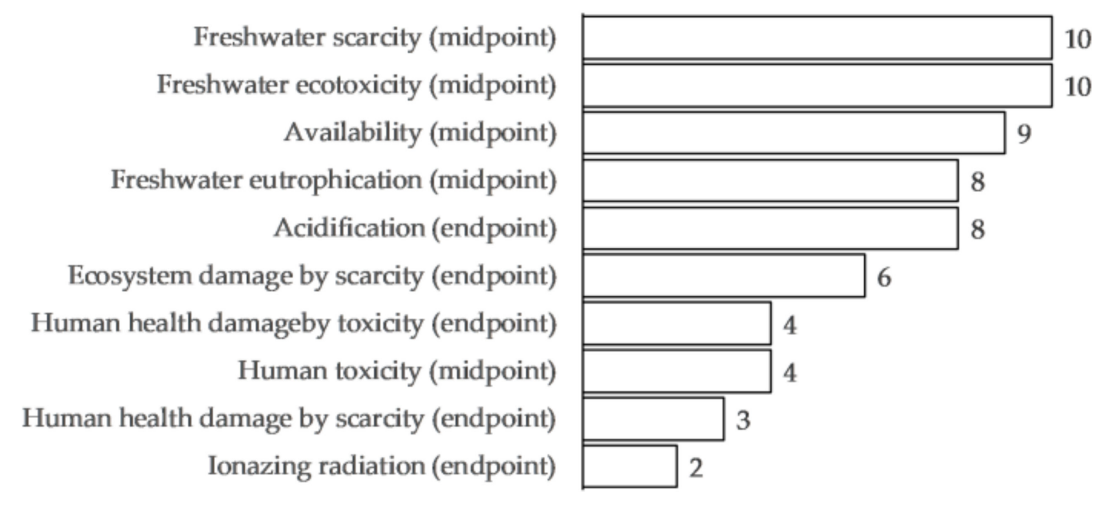

Figure 2. Most used potential environmental impact categories for water footprint studies in Latin America.

During the face-to-face working session, the four most commonly used midpoint impact categories were evaluated through the AHP analysis to be able to recommend suitable impact assessment methods for studies carried out in Latin America. The group discussed many characteristics that should be considered when selecting a method that is adequate to the conditions of the region, and then agreed that the characteristics of recognition, robustness and adaptability, were the most important ones. The impact assessment methods were evaluated against the characteristics with the expert judgement of the group. As a result, the general recommendation shown in Table 4 was obtained regarding the impact categories that should be included in water footprint studies for Latin America for a regional coherence.

Table 4. Recommended impact assessment methods for water footprint studies in Latin America. Modified from CADIS-COSUDE (2016) [18].

\begin{tabular}{cc}
\hline Impact Category & Recommended Impact Method \\
\hline Freshwater scarcity & $\begin{array}{c}\text { AWARE (51\%) } \\
\text { (Boulay et al. 2018) [16] }\end{array}$ \\
\hline Freshwater availability & $\begin{array}{c}\text { Water availability footprint (59\%) } \\
\text { (Boulay et al. 2011) [62] }\end{array}$ \\
\hline Freshwater ecotoxicity & USEtox (75\%) \\
Freshwater eutrophication & (Rosenbaum et al. 2008) [10] \\
\hline ReCiPeMidpoints (55\%) \\
(Goedkoop et al. 2008) [63]
\end{tabular}

\footnotetext{
${ }^{1}$ Values in parentheses correspond to the final weighted values for recommendation obtained during the AHP analysis for each impact assessment method, 100\% represents the total opinions of the working group.
} 


\subsubsection{Regionalization Efforts of Impact Assessment Methods in Latin America}

There have been efforts to regionalize impact assessment methods for evaluating potential environmental impacts related to water use in Latin America. Table 5 shows the studies carried out and the description of the adaptations.

Table 5. Studies carried out to adapt impact assessment methods to the Latin American context. Modified from CADIS-COSUDE (2016) [18].

\begin{tabular}{|c|c|c|}
\hline Study & $\begin{array}{l}\text { Impact Category/ } \\
\text { Impact Assessment Method }\end{array}$ & Description \\
\hline Farell (2013) [51] & $\begin{array}{l}\text { Freshwater scarcity (WSI)/ } \\
\text { Pfister et al. (2009) [64] }\end{array}$ & $\begin{array}{l}\text { The water scarcity index (WSI) was adapted to } \\
\text { the } 13 \text { hydrological-administrative regions of } \\
\text { Mexico. Adaptation was made updating of } \\
\text { data with information from the National Water } \\
\text { Commission (CONAGUA) }\end{array}$ \\
\hline Peña and Huijbregts (2013) [32] & $\begin{array}{l}\text { Freshwater scarcity (WSI)/ } \\
\text { Pfister et al. (2009) [64] }\end{array}$ & $\begin{array}{l}\text { In Chile, the value of the WSI factor for the } \\
\text { northern mining area was regionalized, } \\
\text { obtaining values similar to those reported } \\
\text { globally. }\end{array}$ \\
\hline Marzullo (2014) [30] & Freshwater ecotoxicity & $\begin{array}{l}\text { New methodological approach (at the midpoint } \\
\text { level), uses the impact assessment method } \\
\text { suggested by the Brazilian Agency for the } \\
\text { control of pollution, preservation and } \\
\text { restoration of water quality (CETESB). }\end{array}$ \\
\hline B. Civit (unpublished study) & $\begin{array}{l}\text { Freshwater scarcity (WSI)/ } \\
\text { Pfister et al. (2009) [64] }\end{array}$ & $\begin{array}{l}\text { The WSI factors for Argentina were adapted, } \\
\text { validating with the province of Mendoza, } \\
\text { finding the same results as with the initial } \\
\text { factors. }\end{array}$ \\
\hline Puerto and Gmünder (2014) [65] & $\begin{array}{l}\text { Freshwater scarcity (AWARE)/ } \\
\text { Boulay et al. (2018) [16] }\end{array}$ & $\begin{array}{l}\text { The AWARE characterization factor was } \\
\text { adapted at the sub-basin level using annual } \\
\text { data available in the } 2014 \text { National Water Study } \\
\text { of the Institute of Hydrology, Meteorology and } \\
\text { Environmental Studies (IDEAM). }\end{array}$ \\
\hline de Almeida Castro (2018) [66] & $\begin{array}{l}\text { Freshwater scarcity (WSI and } \\
\text { AWARE)/Pfister et al. (2009) [64] } \\
\text { and Boulay et al. (2018) [16] }\end{array}$ & $\begin{array}{l}\text { The use of national data at State Hydrographic } \\
\text { Unit (SHU) provided results with significant } \\
\text { differences regarding results from original } \\
\text { characterization models. }\end{array}$ \\
\hline
\end{tabular}

The stakeholder group showed interest to create a broader research program to develop impact assessment methods specific for the Latin American region, however this initiative needs structural backup that is difficult to achieve through the dynamic of the recently established community of practice (webinars and face-to-face meetings). However, there are options to foster the development of these initiatives through regional events, such as the Latin American Congress on Life Cycle Assessment (CILCA), which has been recognized by the group, as an event for emphasis and dialogue about regional development and consensus of impact assessment methods.

\subsection{Recommendations for the Communication of the Water Footprint in Latin America}

Regarding the communication of results of water footprint studies in Latin America, the working group concluded that the type of communication depends on the intended audience, as shown in Table 6. 
Table 6. Recommendations for good practices during the communication of the results of water footprint studies in Latin America. Modified from CADIS-COSUDE (2016) [18].

\begin{tabular}{|c|c|}
\hline Intended Audience & Recommended Communication Strategy \\
\hline Civil society & Environmental labels \\
\hline Consumers & Environmental labels \\
\hline Non-Governmental Organizations & Environmental labels \\
\hline Company directors & Executive report or communication report \\
\hline Technical Engineers & Detailed report according to ISO 14046:2014 \\
\hline Verification body & Detailed report according to ISO 14046:2014 \\
\hline $\begin{array}{l}\text { Government entities responsible for the management } \\
\text { of water resources }\end{array}$ & $\begin{array}{c}\text { Communication report } \\
\text { Environmental labels } \\
\text { Detailed report according to ISO 14046:2014 }\end{array}$ \\
\hline Ministries or secretaries of the environment & Communication report \\
\hline $\begin{array}{c}\text { Authorities in charge of sustainable public } \\
\text { procurement }\end{array}$ & Environmental labels \\
\hline
\end{tabular}

The group identified that organizations may choose to document the results of a water footprint study in a "communication report", which is presented in three different levels according to its depth-an executive report, a general water footprint communication report (not too technical) and a ISO 14046:2014 compliant report (detailed). The "communication report" can also be embedded in organizations' annual performance report and/or their sustainability report. Another way of communication is through ecolabeling (environmental labels and declarations), which allow to share the results of a water footprint study with the market, through the presentation of verifiable and accurate information, under a certification scheme.

Regarding the "communication report", the working group recommended standardizing the structure of the detailed report according to ISO 14046:2014 for water footprint studies developed in Latin America, to facilitate the communication and identification of relevant aspects of each study, such as system boundaries, data quality requirements, results and study interpretation, among others [18].

With respect to ecolabeling, some countries in the region have been working towards the implementation of an environmental ecolabel, which includes water related impacts; whilst others have focused specifically on the verification (Costa Rica) or the accreditation (México) of the water footprint. The growing number of EPDs developed in the region certified through Latin American Hub of the International EPD System will also help promote the communication of water footprints, since water scarcity and eutrophication are part of the default environmental impact categories that need to be quantified and reported in an EPD.

It was identified that if an ecolabeling scheme is selected, an independent third-party critical review and verification process is needed to ensure credibility and recognition when communicating with civil society, consumers and non-governmental organizations. In this case, it is advised that a complete report according to ISO 14046:2014 is available to complement the label.

The third-party verification of water footprint studies is a key to provide market position, and it has been identified by the members of the group as one of the main added values. A broad recommendation in this regard was that the verification should include the critical review process, requested by ISO 14046:2014 when it is intended to communicate to third parties [18].

\section{Final Remarks and Prospects}

It is important to highlight that the recommendations provided in the Regional Guidelines foster the consideration of the advancements in research and knowledge evolution, mainly with regards to the category indicators and impact assessment methods. 
It is also important to consider that the following recommendations and consensus for water footprint practice in Latin America: Does not overlook the needed scientific rigor in this type of studies and promotes transparency; the studies in Latin American should report uncertainty, avoid the promotion of immature methods and the obstruction of scientific progress [11].

Consequently, during 2018 the activity of the community of practice focused on capacity building and consolidating the group of active and interested professionals in the field. Afterwards, the process aimed at strengthening the links between other relevant stakeholders in the region (academy, private sector, consultancy groups), increasing the number of studies, training companies for the development of internal water footprint studies and discussing solutions to limitations or opportunities identified in the Regional Guidelines.

\section{Conclusions}

The aim of this study was to generate recommendations to achieve consistency in the quantification, verification and communication of the water footprint in Latin America. A stakeholder group was formed for this purpose, and their active work over six months, was the basis to develop the Regional Guidelines for water footprint assessment in Latin America.

Water footprint assessment of products with life cycle perspective in Latin America is a relatively recent practice, from 2011. However, in recent years there is a growing effort in the region to consolidate the water footprint as a strategic water management tool, and an important number of studies have been carried out; 40 studies were identified in this research. A large number of these studies (31 studies) focused on agricultural products or the agrifood sector; therefore, one important recommendation derived from this study is to strengthen the current work in this sector, through the development of coherent data and impact assessment methods.

Regarding the collection of relevant and good quality data for water footprint studies, the study shows that the main problems found in the region are, unavailability of local or representative data, insufficiency of measurement and monitoring mechanisms, and the issues of the access to information, many times due to confidentiality. Considering these obstacles, the dissemination of the relevance and benefits of the ISO 14046:2014 standard, as well as of that of corporate water management, was found to be a key activity to ease the collection of the data needed in the studies.

One main area of concern in this work was to provide recommendations regarding the quantification of the potential environmental impacts. Therefore, a main outcome of this research was the recommendation of the impact assessment methods to use for the freshwater scarcity, availability, ecotoxicity and eutrophication impact categories. Also, another relevant point was to consider the type of product being assessed when selecting to include or exclude impact categories; and to pay attention to the needs of the intended audience, for example category midpoints were recommended to audiences where there is a need to conserve the objectivity and scientific robustness of the impact categories assessed.

Further research must be done to continue with the development of impact assessment methods, as well as for the development of studies in Latin America to build a regionalized life cycle database for water footprint assessment. This effort is key in the agricultural sector, which poses significant risk against the sustainable use of the resource in the region.

On the other hand, it was found that the recommended mechanism for the communication of results varies depending on the intended audience, for example civil society and NGOs need more sustained and convincing information that needs the rigorousness of an environmental labeling scheme. Business to business communication, such as that of the internal members of organizations, can be fulfilled with a communication report. In the case of sustainable public purchasing, a label is needed. It was found that in the case of communication to expert practitioners, verification bodies and some government initiatives, the detailed ISO 14046 report needs to be provided.

Based on the findings of this research, the Latin American region is clearly leading the way in the development and implementation of water footprint verification and accreditation schemes. Based on 
these experiences it has been found that independent third-party verification and critical review of water footprint studies are essential to ensure credibility and recognition when communicating results.

As an outcome of the work described in this paper, a community of practice was created from a stakeholder group, which participated in the development of the recommendations for the Regional Guidelines. The stakeholder group had representatives from different sectors from 14 countries of the region. The members of the community of practice have been working on the development of studies with the aim of regionalization of evaluation methods to reduce uncertainty linked to category indicators. In this regard, this research identified five studies on regionalization for water scarcity and one for freshwater ecotoxicity methods. In fact, the group understands the importance to develop impact assessment methods specific for the Latin American region, which is a topic to be considered in the future activities of the community of practice.

This water footprint community of practice is growing with the objective of promoting the application of the water footprint methodology according to ISO 14046:2014, and of promoting consensus among several stakeholders. It was envisaged that the strengthening of a community of practice requires consolidation through capacity building, that takes advantage of different participants know how and links.

Supplementary Materials: The document with the detailed results of this initiative is available online at http: //www.elaguanosune.org/gestion-del-conocimiento/comunidad-de-practica/.

Author Contributions: Conceptualization, D.R. and N.S.; Methodology, M.P. and J.P.C.; Formal Analysis, A.M.-A.; Writing-Original Draft Preparation, A.M.-A.; Writing-Review and Editing, N.S.; Supervision, D.R.; Project Administration, M.P. and J.P.C.

Funding: Funding for this study was provided by Swiss Agency for Development and Cooperation (SDC), Swiss Embassy in Colombia, Contract number 81043176/1.

Acknowledgments: We appreciate the collaboration of the Latin American stakeholders representatives who took part in this initiative: Alejandro Conza, Ana Alicia García Ahumada, Andrea Vera, Bárbara Civit, Carlos Naranjo, Carlos Toro, Carole Farell, Claudia Diaz Yanez, Claudia Peña, Cristian Grisales, Daniel Eduardo Ayes, Eduardo Sacayón, Elena Rosa, Ines Francke, Jenny Victoria, João Castro, Julieth Villarraga, Laura Barrantes, Leandra Díaz, Leonidas Letelier, Luis Rodríguez, Manuel González, Noemí Petrocelli, Pablo Lloret, Rita Monteiro, Rony Laura, Sebastián Papi, Seidy Alfaro, SimonGmünder, Valeria Revilla, Verónica Charlón, Carmen Alicia Parrado, Claudia Galleguillos, Jacobo Carrizales, Julio Alejandro Giraldo, María Cristina Argudo, Martha Rodriguez, Nohra León, Patricia Güereca.

Conflicts of Interest: The authors declare no conflict of interest. The authors from the Swiss Agency for Development and Cooperation (SDC) develop this knowledge dissemination action as part of their work activities, without profits derived from it.

Disclaimer: The views and opinions expressed in this article are those of the authors and do not necessarily reflect the official position of the Swiss Agency for Development and Cooperation (SDC).

\section{References}

1. World Economic Forum. The Global Risks Report 2016, 11th ed.; World Economic Forum: Geneva, Switzerland, 2016.

2. UNECLAC/UNW-DPAC. Water and a Green Economy in Latin America and the Caribbean (LAC); UNECLAC/UNW-DPAC: Santiago, Chile, 2012.

3. Hoekstra, A.Y.; Chapagain, A.K.; Aldaya, M.M.; Mekonnen, M.M. The Water Footprint Assessment Manual; Earthscan: London, UK, 2011.

4. ISO 14046:2014 Environmental Management_Water Footprint_Principles, Requirements and Guidelines; ISO: Geneva, Switzerland, 2014.

5. Iniciativa El Agua Nos Une-SuizAgua. Available online: http:/ /www.elaguanosune.org/ (accessed on 4 October 2018).

6. Centro Nacional de Producción Más Limpia y Tecnologías Ambientales; Agrícola Sara Palma; Argos; Clariant; Familia; Griffith Laboratories; Haceb; Holcim; Mineros; Syngenta; Uniban; Quantis Int.; et al. Resultados del Proyecto SuizAgua Colombia. 2015. Available online: https:/ / www.shareweb.ch/site/ElAguaNosUne/ Documents/150427_Publicacion_Resultados_empresariales.pdf (accessed on 8 July 2016). 
7. Fundación Chile; Agualimpia. Manual de Aplicación para Evaluación de Huella Hídrica acorde a la Norma ISO 14046; elaborado bajo el marco del proyecto SuizAgua de la Agencia Suiza para la Cooperación y el Desarrolllo COSUDE; Fundación Chile, Agualimpia, COSUDE: Santiago de Chile, Chile, 2016; Available online: https://www.shareweb.ch/site/ElAguaNosUne/Documents/160405_Manual_aplicacion_ ISO14046_final.pdf (accessed on 8 July 2016).

8. ISO/TR 14073:2017 Environmental Management-Water footprint_Illustrative Examples on How to Apply ISO 14046; ISO: Geneva, Switzerland, 2017.

9. ISO 14046-Environmental Management-Water Footprint-A Practical Guide for SMEs; ISO: Geneva, Switzerland, 2017.

10. Hauschild, M.Z.; Huijbregts, M.; Jolliet, O.; Macleod, M.; Margni, M.; Van De Meent, D.; Rosenbaum, R.K.; McKone, T.E. Building a model based on scientific consensus for life cycle impact assessment of chemicals: The search for harmony and parsimony. Environ. Sci. Technol. 2008, 42, 7032-7037. [CrossRef] [PubMed]

11. Huijbregts, M. A critical view on scientific consensus building in life cycle impact assessment. Int. J. Life Cycle Assess. 2014, 19, 477-479. [CrossRef]

12. European Commission-Joint Research Centre-Institute for Environment and Sustainability. International Reference Life Cycle Data System (ILCD) Handbook-Recommendations for Life Cycle Impact Assessment in the European Context, 1st ed.; Publications Office of the European Union: Luxembourg, 2011.

13. Lovarelli, D.; Bacenetti, J.; Fiala, M. Water Footprint of crop productions: A review. Sci. Total Environ. 2016, 548-549, 236-251. [CrossRef] [PubMed]

14. Aivazidou, E.; Tsolakis, N.; Iakovou, E.; Vlachos, D. The emerging role of water footprint in supply chain management: A critical literature synthesis and a hierarchical decision-making framework. J. Clean. Prod. 2016, 137, 1018-1037. [CrossRef]

15. Creswell, J.W. Research Design: Qualitative, Quantitative and Mixed Methods Approaches, 4th ed.; SAGE Publications, Inc.: Thousand Oaks, CA, USA, 2014; ISBN 978-1-4522-2609-5.

16. Boulay, A.M.; Bare, J.; Benini, L.; Berger, M.; Lathuillière, M.J.; Manzardo, A.; Margni, M.; Motoshita, M.; Núñez, M.; Pastor, A.V.; et al. The WULCA consensus characterization model for water scarcity footprints: Assessing impacts of water consumption based on available water remaining (AWARE). Int. J. Life Cycle Assess. 2018, 23, 368-378. [CrossRef]

17. Heo, Y. Methodology for Prioritizing DfE Strategies Based on LCA and AHP; Ajou University: Suwon, Korea, 2001.

18. Centro de Análisis de Ciclo de Vida y Diseño Sustentable CADIS; Embajada de Suiza en Colombia; Agencia Suiza para la Cooperación y el Desarrollo COSUDE; Martínez, A.; Chargoy, J.; Puerto, M.; Suppen, N.; Rojas, D.; Alfaro, S.; Ayes, D.; et al. Huella de Agua (ISO 14046) en América Latina, Análisis y Recomendaciones Para Una Coherencia Regional; Centro de Análisis de Ciclo de Vida y Diseño Sustentable CADIS, Embajada de Suiza en Colombia, Ayuda Humanitaria y Desarrollo COSUDE: Ciudad de México, Mexico, 2016; 90p, Available online: https://www.researchgate.net/publication/314329199_Huella_de_Agua_ISO_14046_en_ America_Latina_analisis_y_recomendaciones_para_una_coherencia_regional (accessed on 10 July 2018).

19. Arena, A.P.; Piastrellini, R.; Civit, B. Water footprint of soybean production in Argentina. In Proceedings of the Lcm 2011, Berlin, Germany, 28-31 August 2011; p. 7.

20. Alvarez, H.J.; Larripa, M.J.; Galli, J.R.; Civit, B.M. Inventario de la huella de agua en sistemas lecheros diferenciados por el uso de la tierra y el nivel de suplementación. In $36^{\circ}$ Congreso Argentino de Producción Animal; INTA: Ciudad de Corrientes, Argentina, 2013; Volume 33.

21. Anschau, R.A.; Bongiovanni, R.; Tuninetti, L.; Manazza, F. Huella hídrica de la cadena de maní en Argentina. In Actas del IV Encuentro Argentino de Ciclo de Vida y III Encuentro de la Red Argentina de Huella Hídrica Enarciv 2015; Bongiovanni, R., Tuninetti, L., Eds.; INTA: Buenos Aires, Argentina, 5-6 November 2015; pp. 16-20.

22. Civit, B.; Piastrellini, R.; Curadelli, S.; Arena, P. Medida del impacto sobre la calidad de agua en la etapa de producción de productos. In Actas del IV Encuentro Argentino de Ciclo de Vida y III Encuentro de la Red Argentina de Huella Hídrica Enarciv 2015; Bongiovanni, R., Tuninetti, L., Eds.; INTA: Buenos Aires, Argentina, 5-6 November 2015; pp. 21-25.

23. San Luis Agua, S.E.; Ministerio del Campo; Gobierno de la Provincia de San Luis. Cálculo y Análisis de la Huella Hídrica de la Provincia de San Luis. Sectores Agrícola y Pecuario; Gobierno de la Provincia de San Luis: San Luis, Argentina, 2014; Available online: http:/ / www.huellahidrica.org/Reports / Calculo\%20Huella\% 20Hidrica.pdf (accessed on 8 July 2016). 
24. Charlon, V.; Tieri, M.P.; Manazza, F.; Engler, P.; Pece, M.A.; Frank, F.C. Comparación de dos metodologías de cálculo de huella hídrica en un sistema de producción de leche de argentina. In Proceedings of the Actas del III Encuentro Argentino de Ciclo de Vida y II Encuentro de la Red Argentina de Huella Hídrica ENARCIV 2014, Mendoza, Argentina, 2-5 September 2014.

25. Banco de desarrollo de América Latina. Proyecto Huella de Ciudades: Resultados Estratégicos y Guía Metodológica; Flores, V., Ed.; Development Bank of Latin America: La Paz, Bolivia, 2015; ISBN 9789804220289.

26. águaBrasil. Pegada Hídrica das Bacias Hidrográficas. 2014. Available online: https://www.bb.com.br/docs/ pub/siteEsp/uds/dwn/pegadahidrica.pdf (accessed on 8 July 2016).

27. Francke, I.C.M.; Castro, J.F.W. Applying the water footprint methodology in a cosmetic company: Lessons from Natura Cosméticos, Brazil. In Proceedings of the Session "Solving the Water Crisis: Common Action toward a Sustainable Water Footprint", Planet under Pressure Conference, London, UK, 26 March 2012; Zhang, G.P., Hoekstra, A.Y., Tickner, D., Eds.; UNESCO-IHE Institute for Water Education: Delft, The Netherlands, 2012.

28. Ferreira, F.F. Pegada Hídrica da Geração de Energia Hidrelétrica no Brasil-Um Estudo de Caso da AES TIETÊ S.A.; Federal University of Rio de Janeiro: Rio de Janeiro, Brasil, 2014.

29. Silva, V.P.R.; Maracajá, K.F.B.; Araújo, L.E.; Dantas Neto, J.; Aleixo, D.O.; Campos, J.H.B.C. Pegada hídrica de indivíduos com diferentes hábitos alimentares. Rev. Ambient. Água 2013, 8, 250-262. [CrossRef]

30. Marzullo, R.d.C.M. Metodologia para o Cálculo da Pegada Hídrica Ecotoxicológica de Produtos dentro de uma Perspectiva de ACV com Uso do GIS: Estudo Piloto para o Etanol Hidratado; University of São Paulo: São Paulo, Brasil, 2014.

31. Fundación Chile. Reporte Huella Hídrica en Chile Sectores Prioritarios de la Cuenca del río Rapel; Fundación Chile: Santiago de Chile, Chile, 2016.

32. Peña, C.A.; Huijbregts, M.A. The Blue Water Footprint of Primary Copper Production in Northern Chile. J. Ind. Ecol. 2014, 18, 49-58. [CrossRef]

33. Fundación Chile. Evaluación de Huella Hídrica al Site Maipú de Clariant acorde a la Norma ISO14046; Fundación Chile: Santiago de Chile, Chile, 2015.

34. Water Week Latinoamerica 2015, Slideshows: Tinguiririca Energía, Nestlé Chile, Mall Plaza, Clariant. Available online: https: / issuu.com/suizagua (accessed on 8 July 2016).

35. Arevalo, D.; Lozano, J.G.; Sabogal, J. Estudio nacional de Huella Hídrica Colombia Sector Agrícola. Rev. Int. Sosten. Tecnol. Hum. 2011, 7, 103-126.

36. CTA; GSI-LAC; COSUDE; IDEAM. Evaluación Multisectorial de la Huella Hídrica en Colombia. Resultados por Subzonas Hidrográficas en el Marco del Estudio Nacional del Agua 2014; Centro de Ciencia y Tecnología de Antioquia: Medellín, Colombia, 2015; ISBN 978-958-8470-28-3.

37. Centro de Ciencia y Tecnología de Antioquia. Evaluación De La Huella Hídrica En La Cuenca Del Río Porce; Centro de Ciencia y Tecnología de Antioquia: Antioquia, Colombia, 2013.

38. Rojas Vanegas, Y.; Ramirez Vera, L.; Ortega Torres, J. Evaluacion de la Huella Hidrica del Lirio Japones. Water Footpr. Jpn. Lily (Hemerocallis) 2013, 1, 10. [CrossRef]

39. Echeverri Bedoya, X.V. Estimación de la Huella Hídrica en la Extracción de Caliza a Cielo Abierto y Propuesta de Una Política de Integración Sostenible del Recurso Hídrico-Caso Planta Rioclaro, Argos; Universidad Nacional de Colombia: Medellín, Colombia, 2014.

40. Morales, H.; Quevedo, L.; Ospina, J.; Florez, E.; Guzmán, P.; Monserrate, F.; Ospina, F.; Orrego, M.; Romero, M.; Carabali, T.; et al. Estimaciones comparativas de huella hídrica en Arroz: Manejo AMTEC vs Convencional. In Memorias Taller Huella Hídrica y de Carbono en la Agricultura Colombiana; Ministerio de Agricultura, CIAT, CGIAR, CCAFS: Bogotá, Colombia, 2014; Available online: http:/ / www. aclimatecolombia.org/recursos-de-informacion/?wpfb_list_page=2 (accessed on 8 July 2016).

41. Parrado, C. Huella hídrica en el sector floricultor colombiano. In Memorias Taller Huella Hídrica y de Carbono en la Agricultura Colombiana; Ministerio de Agricultura, CIAT, CGIAR, CCAFS: Bogotá, Colombia, 2014; Available online: http:/ / www.aclimatecolombia.org/recursos-de-informacion/ ?wpfb_list_page=2 (accessed on 8 July 2016).

42. Ortiz-Rodriguez, O.O.; Naranjo, C.A.; García-Caceres, R.G.; Villamizar-Gallardo, R.A. Water footprint assessment of the Colombian cocoa production. Rev. Bras. Eng. Agrícola Ambient. 2015, 19, 823-828. [CrossRef]

43. Quintero, M.; Romero, M.; Tapasco, J.; Monserrate, F.; Molina, C.; Román, N.; Coral-Eraso, D. Huella hídrica en el cultivo del maíz. In Memorias Taller Huella Hídrica y de Carbono en la Agricultura Colombiana; 
Ministerio de Agricultura, CIAT, CGIAR, CCAFS: Bogotá, Colombia, 2014; Available online: http:/ / www. aclimatecolombia.org/recursos-de-informacion/?wpfb_list_page=2 (accessed on 8 July 2016).

44. Otero, W.; Solanilla, R.; Cifuentes, A.; Garcia, J.; Monserrate, F.; Romero, M.; Quintero, M.; Valencia, J.; Carabalí, T. Estimación de la huella hídrica en papa: Comparación entre agricultura de conservación y agricultura tradicional en Cundinamarca. In Memorias Taller Huella Hídrica y de Carbono en la Agricultura Colombiana; Ministerio de Agricultura, CIAT, CGIAR, CCAFS: Bogotá, Colombia, 2014; Available online: http:/ / www.aclimatecolombia.org/recursos-de-informacion/?wpfb_list_page=2 (accessed on 8 July 2016).

45. HIDROCEC-UNA. Aplicación del Cálculo de Huella Hídrica para Regiones de Cultivos de Café, Banano y Arroz en Costa Rica; Instituto Interamericano de Cooperación para la Agricultura: San José, Costa Rica, 2013.

46. Vallejo, A.L. Metodología Práctica para la Cuantificación de la Huella de Agua en Plantas Empacadoras de Banano en Costa Rica; Escuela de Química, Instituto Tecnológico de Costa Rica: Cartago, Costa Rica, 2015; p. 108.

47. Zarate, E.; Kuiper, D. Evaluación de Huella Hídrica del Banana para Pequeños Productores en Perú y Ecuador; Good Stuff International: Bowil, Switzerland, 2013; p. 70.

48. Vernaza, E. La Huella Hídrica y el Agua Virtual de las Rosas: Como el Uso, Consumo y Aprovechamiento del Agua Tiene Impacto Dentro de la Cadena de Suministro de la Industria Florícola; Universidad San Francisco de Quito: Quito, Ecuador, 2014.

49. AgroDer. Huella Hídrica en México en el Contexto de Norteamérica; WWF México y AgroDer: Distrito Federal, Mexico, 2012.

50. Farell, C.; Turpin, S.; Suppen, N. Huella de agua de uso público-urbano en México. Rev. Int. Estadística y Geogr. 2013, 4, 58-71.

51. Farell, C. Diseño de una Metodología para Reportar la Huella de Agua; Universidad Autónoma Metropolitana Unidad Azcapotzalco: Mexico City, Mexico, 2013.

52. Agualimpia; Mexichem; Quantis; Agencia Suiza para la Cooperación COSUDE; Campillo, C.; Conza, A.; Alfaro, B.; Laura, R.; Vionnet, S.; Gmuender, S.; et al. Análisis de Huella Hídrica en la Planta de Fabricación de Tuberías en el Agustino. 2015. Available online: https://www.shareweb.ch/site/ElAguaNosUne/ Documents/15_SuizAgua\%20PE-huella_hidrica_planta_tuberias_El_Agustino_Pavco.pdf (accessed on 8 July 2016).

53. Agualimpia; Camposol; Quantis; Agencia Suiza para la Cooperación COSUDE; Campillo, C.; Conza, A.; Alfaro, B.; Laura, R.; Vionnet, S.; Gmuender, S.; et al. Análisis de Huella Hídrica en los Campos de Cultivo de Espárrago de Camposol acorde a la Norma ISO14046. 2015. Available online: https://www.shareweb.ch/site/ElAguaNosUne/Documents/15_SuizAgua\%20PE-Analisis_huella_ hidrica_Campos_Esparrago_Camposol.pdf (accessed on 8 July 2016).

54. Agualimpia; Nestlé; Quantis; Agencia Suiza para la Cooperación COSUDE; Conza, A.; Alfaro, B.; Laura, R.; Reyes, J.G.; Vionnet, S.; Gmuender, S.; et al. Informe de Evaluación de Huella Hídrica del Helado Donito de Lúcuma y Vainilla en la Fábrica Donofrio. 2015. Available online: https://www.shareweb.ch/site/ElAguaNosUne/Documents/15_SuizAgua\%20PEEvaluacion_huella_hidrica_Helado_Donito_Lucuma_Nestle.PDF (accessed on 8 July 2016).

55. Agualimpia; Duke Energy; Quantis; Agencia Suiza para la Cooperación COSUDE; Conza, A.; Alfaro, B.; Laura, R.; Espinoza, R.; Vionnet, S.; Gmuender, S.; et al. Análisis de Huella Hídrica en la Central Termoeléctrica "Aguaytia" acorde a la Norma ISO14046. 2015. Available online: https:/ / www.shareweb.ch/site/ElAguaNosUne/Documents/15_SuizAgua\%20PE-Evaluacion_huella_ hidrica_Termoelectrica_DukeE_Peru.pdf (accessed on 8 July 2016).

56. Mekonnen, M.M.; Pahlow, M.; Aldaya, M.M.; Zarate, E.; Hoekstra, A. Water Footprint Assessment for Latin America and the Caribbean: An Analysis of the Sustainability, Efficiency and Equitability of Water Consumption and Pollution, Value of Water Research Report Series No. 66; UNESCO-IHE Institute for Water Education: Delft, The Netherlands, 2014.

57. Ran, Y.; Deutsch, L.; Lannerstad, M.; Heinke, J. Rapidly Intensified Beef Production in Uruguay: Impacts on Water-related Ecosystem Services. Aquat. Procedia 2013, 1, 77-87. [CrossRef]

58. Lovarelli, D.; Ingrao, C.; Fiala, M.; Bacenetti, J. Beyond the Water Footprint: A new framework proposal to assess freshwater environmental impact and consumption. J. Clean. Prod. 2018, 172, 4189-4199. [CrossRef]

59. UN-WWAP. The United Nations World Water Development Report 2015: Water for a Sustainable World; UN-WWAP: Paris, France, 2015. 
60. Morillo, J.G.; Díaz, J.A.R.; Camacho, E.; Montesinos, P. Linking water footprint accounting with irrigation management in high value crops. J. Clean. Prod. 2015, 87, 594-602. [CrossRef]

61. Bare, J.C.; Hofstetter, P.; Pennington, D.W.; Udo de Haes, H.A. Midpoints versus endpoints: The sacrifices and benefits. Int. J. Life Cycle Assess. 2000, 5. [CrossRef]

62. Boulay, A.-M.; Bulle, C.; Bayart, J.-B.; Deschênes, L.; Margni, M. Regional Characterization of Freshwater Use in LCA: Modeling Direct Impacts on Human Health. Environ. Sci. Technol. 2011, 45, 8948-8957. [CrossRef] [PubMed]

63. Goedkoop, M.; Heijungs, R.; De Schryver, A.; Struijs, J.; van Zelm, R. ReCiPe 2008. A LCIA Method Which Comprises Harmonised Category Indicators at the Midpoint and the Endpoint Level; Ministry of Housing, Spatial Planning and the Environment: The Hague, The Netherlands, 2013.

64. Pfister, S.; Koehler, A.; Hellweg, S. Assessing the Environmental Impacts of Freshwater Consumption in LCA. Environ. Sci. Technol. 2009, 43, 4098-4104. [CrossRef] [PubMed]

65. Puerto, M.; Gmünder, S. Regionalizing AWARE per Hydrographic Subzone of Colombia; The International Life Cycle Conference in Latin America (CILCA for Its Acronym in Spanish): Medellín, Colombia, 2017; Available online: http://www.elaguanosune.org/gestion-del-conocimiento/estudios-de-caso/ colombia / aware-para-subzonas-hidricas-de-colombia-metodo-de-boulay-et-al-2016-datos-anuales-paraano-promedio-y-ano-seco-del-ena-2014-ideam/ (accessed on 11 July 2017).

66. De Almeida Castro, A.L.; Pereira Andrade, E.; de Alencar Costa, M.; de Lima Santos, T.; Lie Ugaya, C.M.; Brito de Figueirêdo, M.C. Applicability and relevance of water scarcity models at local management scales: Review of models and recommendations for Brazil. Environ. Impact Assess. Rev. 2018, 72, 126-136. [CrossRef]

(C) 2018 by the authors. Licensee MDPI, Basel, Switzerland. This article is an open access article distributed under the terms and conditions of the Creative Commons Attribution (CC BY) license (http:/ / creativecommons.org/licenses/by/4.0/). 